\title{
Return of splenic function after splenectomy: how much tissue is needed?
}

\author{
G R CORAZZA, C TAROZZI, D VAIRA, M FRISONI, G GASBARRINI
}

\begin{abstract}
Ninety patients whose spleen had been removed either because of trauma ( 41 cases) or as an elective procedure (49) were investigated for return of splenic function by counting pitted red cells and examining spleen scans made after injection of heat damaged ${ }^{9} \mathrm{~m}$ Tc labelled red cells.

There was no significant difference in the proportion of pitted red cells between the two groups of patients. Evidence of splenic tissue in scintiscans was not invariably associated with low pitted red cell values, suggesting that the presence of splenic tissue did not necessarily mean return of splenic function. In every patient whose proportion of pitted red cells was less than $16.2 \%$ the scintiscan showed splenic uptake. The proportion of patients with pitted red cell values below $16.2 \%$ was significantly higher in the group operated on for trauma, and it is concluded that this was due to splenosis. A high inverse correlation between pitted red cell counts and computed splenic volumes was found. Patients with pitted red cell values of less than $16.2 \%$ had computed volumes of $22-133 \mathrm{~cm}^{3}$; below this range the proportion of pitted red cells rose very sharply.

These results confirm that splenosis occurs in adults, though less often than in children, and suggest that when splenic tissue is to be implanted a graft of at least $20-30 \mathrm{~cm}^{3}$ is needed to ensure satisfactory return of splenic function.
\end{abstract}

Third Department of Medical Pathology, Policlinico S Orsola, University of Bologna, and Nuclear Medicine Unit, Ospedale Maggiore, Bologna, Italy

G R CORAZZA, MD, assistant in medical pathology

C TAROZZI, MD, assistant in nuclear medicine

$D$ VAIRA, MD, research fellow

$M$ FRISONI, MD, research fellow

G GASBARRINI, MD, professor of medical pathology

Correspondence to: Dr G R Corazza, III Patologia Medica, Policlinico $S$ Orsola, Via Massarenti 9, 40100 Bologna, Italy.

\section{Introduction}

Overwhelming sepsis of encapsulated bacteria is a major complication of splenectomy. ${ }^{1-3}$ Although the incidence of fulminant infection is apparently low, an actuarial estimate suggested that $33 \%$ of a non-selected population would suffer at least one serious infection by the end of 10 years after splenectomy. ${ }^{4}$

Among the reasons for splenectomy, trauma is associated with the least risk of subsequent infection. This has been ascribed to restoration of splenic function due to splenosis, ${ }^{25}$ as a result of the heterotopic autotransplantation of tissue from ruptured spleen on to peritoneal surfaces. ${ }^{6}$ By analogy, surgical autotransplantation of splenic tissue has been proposed to lessen the risk of infection after splenectomy. ${ }^{7}$ Nevertheless, although implantation of splenic tissue does occur in animals ${ }^{8}$ and man, ${ }^{9}$ heterotopic splenic tissue may fail to prevent fatal pneumococcal septicaemia in rats ${ }^{10}$ and occasionally in man. ${ }^{11}$ These failures may have several explanations, but the volume of splenic nodules is thought to be important in the protection against postsplenectomy infection. ${ }^{12}$

We have sought answers to some of these questions by examining (a) the incidence of residual splenic function after removal of the spleen, $(b)$ the relation between tests of residual splenic function and residual splenic tissue, and $(c)$ the amount of tissue needed to restore splenic function in patients after splenectomy.

\section{Patients and methods}

We studied 90 patients who had undergone splenectomy. Of these, 41 had had the operation for traumatic rupture of the spleen-32 (aged 18-70 years, mean 38) for external injury and nine (aged 21-64 years, mean 47.5) for peroperative injury (partial gastrectomy (five cases), chronic pancreatitis (two), cancer of the liver (one), hiatus hernia (one), - and 49 had had an elective procedure. Of this second group, 16 (aged 5-56 years, mean 23) had had their spleens removed during the staging procedure of Hodgkin's disease and 33 (aged 8-68 years, mean 41) had had the operation for non-malignant disease (hypersplenism due to cirrhosis (eight cases), hereditary spherocytosis (six), immune thrombocytopenia (six), autoimmune haemolytic anaemia (five), thalassaemia (three), splenoportal thrombosis (three), Banti's disease (two)).

Patients had had their operations six months to 14 years (mean 5.4 
years) before the study. Splenic function was assessed by counting pitted red cells ${ }^{13}$ - that is, red cells bearing membrane abnormalities visible under interference phase microscopy as "pits." Briefly, one drop of fresh venous blood was mixed with $0.5 \mathrm{ml} 3 \%$ buffered glutaraldehyde solution, $\mathrm{pH} 7 \cdot 4$. One thousand red cells were examined in a wet preparation (magnification $\times 1000$ ) with a direct interference contrast microscope (Leitz Dialux 20, equipped with Nomarsky optics) by an observer who did not know from which subjects the samples had been obtained. A significant inverse correlation exists between the percentage of pitted red cells and splenic function as measured by the clearance of heat damaged red cells, ${ }^{14}$ and the percentage of pitted red cells was therefore taken as a measure of splenic function (upper limit of normal $4 \%{ }^{14}$ ).

In 22 subjects operated on for trauma and eight after elective splenectomy spleen scans were carried out using heat damaged ${ }^{99 \mathrm{~m} T \mathrm{~T}}$ labelled autologous red blood cells prepared according to kit TCK 11 Erythrocis (Cis-Sorin, Gif sur Yvette, France). Forty five minutes after intravenous reinjection of the labelled red cells images of chest and abdomen were obtained using a Searle LFOV camera (Des Plaines, Illinois, USA) equipped with a high resolution, low energy parallel hole collimator. Multiple lateral, anterior, posterior, and oblique views were obtained. For eight out of 17 patients with a positive spleen scan a computer (Dycom 80, El Scint, Haifa, Israel) was used to calculate the volume of splenic tissue according to the ellipsoid formula. ${ }^{15}$

In scintigraphic evaluation of residual splenic tissue no selection other than agreement of the patients to participate was used.

The pitted red cell counts in the various groups of patients were compared using Wilcoxon's rank sum test for unpaired data, Fisher's exact probability test, and $\chi^{2}$ analysis with Yates's correction. The correlation between the percentage of pitted red cells and computed splenic volumes was evaluated by the Spearman rank correlation test.

\section{Results}

Figure 1 shows the pitted red cell counts in the four groups of patients. Only in the group who had had an elective splenectomy was a significant difference found: the percentage of pitted red cells in subjects with malignant diseases was significantly lower than in those with non-malignant diseases (Wilcoxon's rank sum test, $\mathrm{p}<0.01$ ). In none of the four groups was a correlation found between the percentage of pitted red cells and time in years since splenectomy.

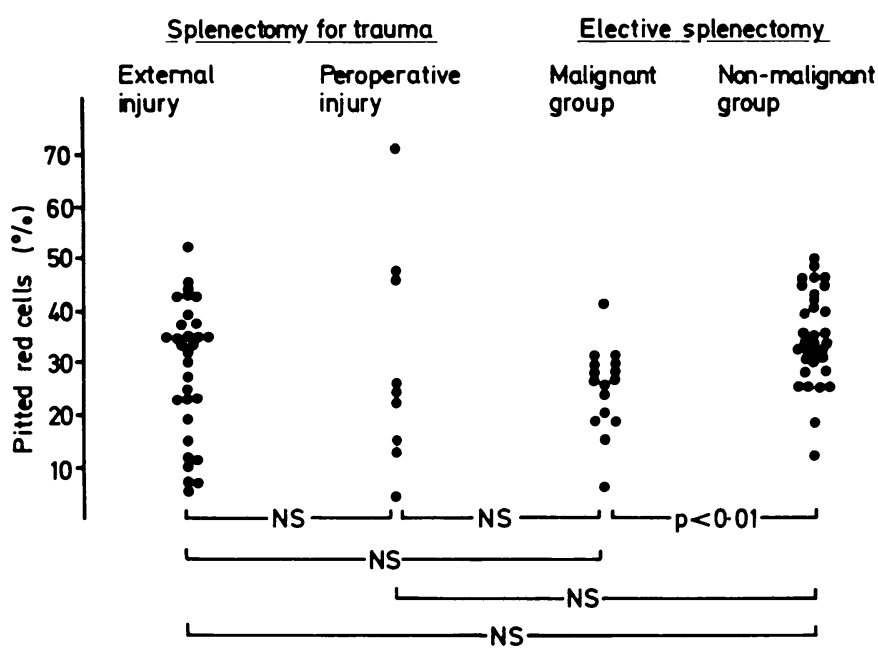

FIG 1-Percentage of pitted red cells in four groups of patients with a history of splenectomy.

Figure 2 shows the percentages of pitted red cells in 30 patients who underwent a spleen scan. The results were divided into two groups according to the presence or absence of splenic activity in the scans. Although splenic activity was detected in $14(64 \%)$ of the patients operated on for trauma as compared with only three $(38 \%)$ of the eight patients whose operations were elective, the difference did not reach significance $(p=0.39$; Fisher's exact test).

The lowest value of pitted red cells in patients without detectable splenic tissue was $16.2 \%$, and below this value scintiscans always showed splenic tissue. Ten $(24 \%)$ of the 41 patients operated on for trauma and three $(6 \%)$ of the 49 who had had elective operations had a pitted red cell value below $16.2 \%$; this difference was significant $\left(p<0.05 ; \chi^{2}\right.$ test with Yates's correction).

Multiple heterotopic nodules of "splenic" uptake (fig 3) were detected in five patients operated on because of injury but in none of those who had had an elective splenectomy.

Figure 4 plots the percentages of pitted red cells against residual computed splenic volumes in the eight patients for whom this information was available. There was a significant inverse correlation between these two measurements. Patients with less than $16.2 \%$ of pitted red cells and positive spleen scintiscans had computed volumes of splenic tissue ranging from 22 to $133 \mathrm{~cm}^{3}$. The lowest pitted red cell value recorded was $4 \cdot 1 \%$, which was very close to the upper limit of the control range quoted in some studies. ${ }^{1416}$ This degree of splenic function was maintained by a residual splenic volume of $133 \mathrm{~cm}^{3}$.

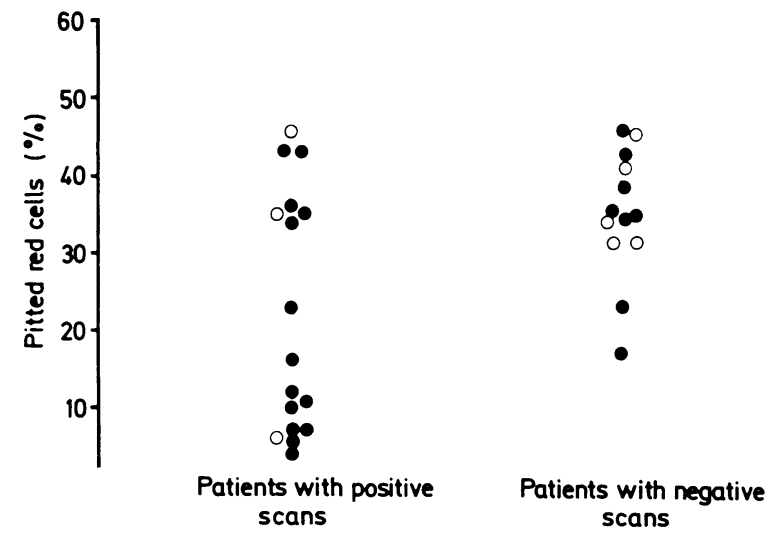

FIG 2-Percentage of pitted red cells in patients after splenectomy with and without splenic tissue detectable on scintiscan. $=$ Patients whose splenectomy was for trauma. $O=$ Patients whose splenectomy was elective.

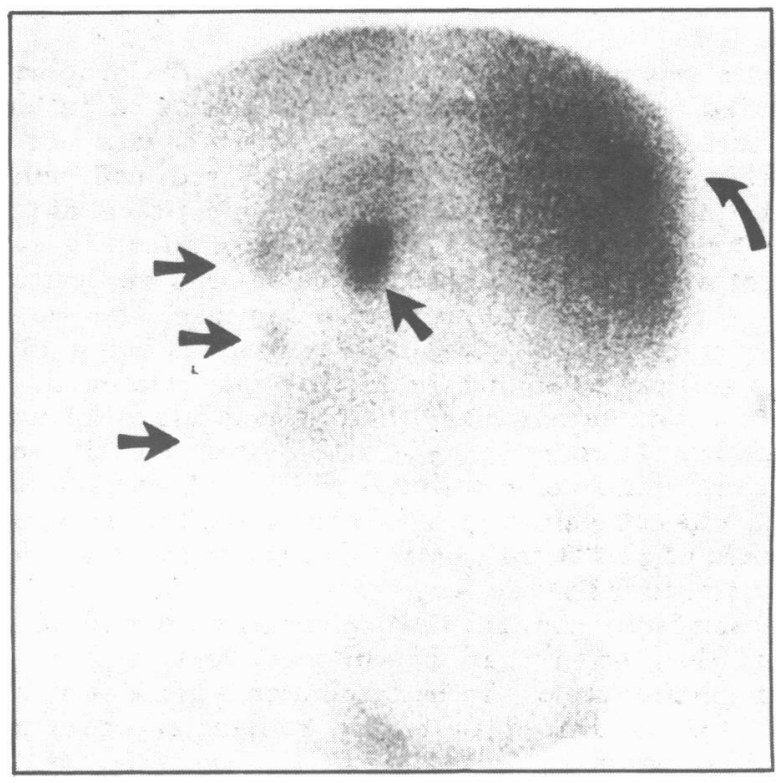

FIG 3-Right posterolateral ${ }^{99} \mathrm{~m}$ Tc splenic scan in 27 year old man six years after splenectomy for trauma. Arrows indicate nodules of splenic activity.

\section{Discussion}

The important role of the spleen in immune defence against infection is confirmed by the occurrence of major sepsis after splenectomy. ${ }^{1718}$ Although the risk of severe infection is thought to be particularly high in children, ${ }^{2}$ a study in adults showed a risk of lethal sepsis 540 times greater than in the population at large. ${ }^{19}$

Splenectomy for trauma is associated with a smaller risk, probably because of a return of splenic function due to 
splenosis. ${ }^{25}$ On the other hand, although splenosis has been produced experimentally, ${ }^{80}$ its occurrence in patients undergoing splenectomy for trauma has been questioned. Positive spleen scans have been reported in about half of patients with a history of splenectomy for trauma, ${ }^{21-23}$ but this high frequency of residual splenic tissue cannot be taken as definite evidence of splenosis. Most of the patients had only one area of increased uptake in the scan, ${ }^{23}$ which may have been an accessory spleen; this is found in $10-44 \%$ of non-splenectomised subjects at necropsy. ${ }^{24}$ Moreover, as splenic nodules of about $3 \mathrm{~cm}$ diameter are not visible in spleen scans, ${ }^{25}$ this technique cannot be regarded as entirely reliable in the detection of splenosis. Counting pitted red cells, however, allows an overall estimate of residual splenic function to which detectable and undetectable splenic tissue contributes.

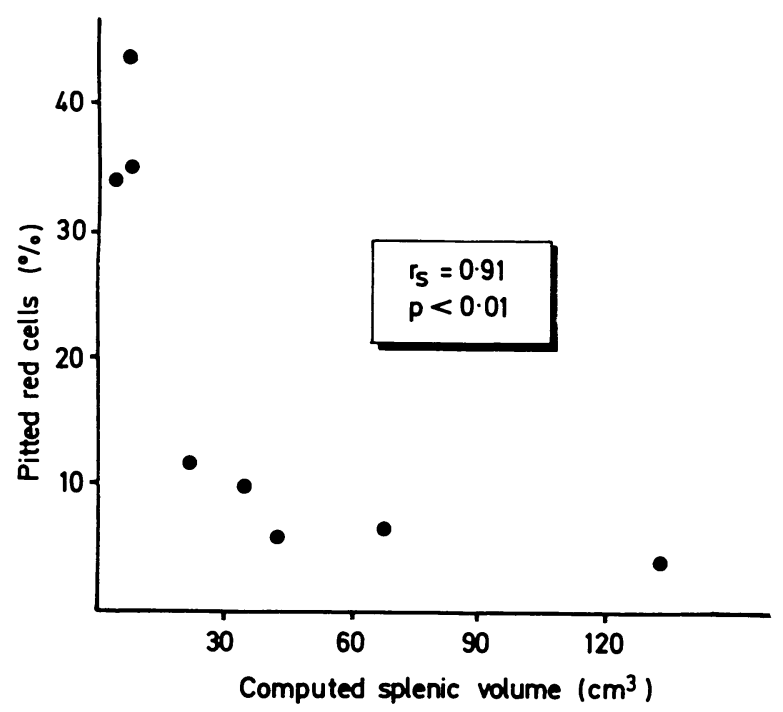

FIG 4-Percentage of pitted red cells plotted against computed splenic volume in eight patients without spleens.

By counting pitted red cells renewed splenic function was documented in 13 out of 22 children whose spleens had been removed after injury. ${ }^{13}$ Such a high incidence of splenosis was not confirmed subsequently. ${ }^{26}$ That study showed a low percentage of pitted red cells, consistent with the presence of residual splenic tissue in only four out of 14 children and one out of 17 adults operated on trauma, suggesting that recurrence of splenic activity in adults, unlike children, is rare. Our results apparently confirm this. In all groups of adults in our study residual splenic function ranged from mild to severe hyposplenism, and no difference in the percentage of pitted red cells was observed among the groups, except in the patients who had had an elective splenectomy. In that group patients with malignant haematological disease had a significantly lower percentage of pitted red cells compared with those who had undergone elective splenectomy for non-malignant diseases. This difference might be explained in several ways. Most of our patients operated on for malignant disease were children, which might account for a higher prevalence of accessory spleens. ${ }^{27}$ Possibly in patients operated on for malignant disease fragments of splenic tissue might have been left owing to adhesion of the spleen to the abdominal wall. ${ }^{21}$

The occurrence in each group of so wide a range of splenic hypofunction makes it difficult to select a pitted red cell value that would indicate the presence of splenosis. By dividing the patients into two groups according to the presence or absence of splenic activity in the spleen scans we confirmed considerable overlap in pitted red cell counts ${ }^{28}$ between the groups, suggesting that the presence of residual splenic tissue is not enough to restore a useful degree of splenic function. Splenic activity in the scan was detected in three out of eight patients $(38 \%)$ given elective operations as compared with 14 out of $22(64 \%)$ operated on for trauma. Although the difference is not significant, the former percentage falls in the range of frequencies for accessory spleens, ${ }^{24}$ while the latter definitely exceeds this range.

Multiple small nodules of splenic tissue were detected in places other than the left upper quadrant only in patients whose splenectomy was for trauma, but this cannot be held as definite evidence of splenosis as accessory spleens have been found in the small and large bowel mesenteries. ${ }^{29}$ On the other hand, as already reported, ${ }^{28}$ the presence of a single area of uptake of radioactivity in the left upper quadrant does not exclude splenosis. In our patients we found that pitted red cell values of less than $16 \cdot 2 \%$ occurred only in the presence of splenic activity in the scintiscans, which confirms previous results. ${ }^{28}$ As the proportion of patients with pitted red cell counts below $16 \cdot 2 \%$ was significantly higher in the post-trauma group $(24.5 \%)$ than in the group of patients who had undergone elective splenectomy $(6.1 \%)$ we infer that the higher frequency of residual splenic tissue in the post-trauma group was due to splenosis.

Our data on pitted red cell counting confirm a return of splenic function after splenectomy for trauma but differ from the data of Pearson et al in the frequency and magnitude of this event. ${ }^{13}$ In contrast to their findings, none of our patients operated on for trauma could be considered to have splenic function clearly within the normal range, and even those with presumptive splenosis would be classified as hyposplenic. This discrepancy might be ascribed to differences in the ages of patients (children in the study of Pearson et al, adults in ours), since splenic cells may lose the ability to implant with age. ${ }^{26}$

Return of splenic function is evident one to three months after implantation of autologous splenic tissue after splenectomy for trauma. ${ }^{9}$ In our study the time from splenectomy to our observations ranged from six months to 14 years, and in this range no correlation between the percentage of pitted red cells and time since splenectomy was found. Beyond the first months after removal of the spleen, therefore, time does not seem to be important for the return of splenic function.

That the percentage of pitted red cells mirrors the presence of differing amounts of regenerated splenic tissue was confirmed by the high inverse correlation that we found between pitted red cell values and computed splenic volume. Patients with values below $16.2 \%$ had computed volumes ranging from 22 to $133 \mathrm{~cm}^{3}$ Below this range the percentage of pitted red cells rose very sharply, whereas the percentage fell slowly towards normal for spleen volumes above $20-30 \mathrm{~cm}^{3}$. These data suggest that $20-30 \mathrm{~cm}^{3}$ of splenic tissue is the "inflection point" above which our parameter of splenic function shows a certain degree of return and under which pitted red cells rapidly reach values at which it might be suspected that splenic immune function is effectively absent. Thus, although it has been proposed that in certain patients undergoing splenectomy a small autograft of spleen might prevent deaths due to fulminant septicaemia, ${ }^{7}$ it appears evident that the mere presence of splenosis is not sufficient to ensure satisfactory return of splenic function. Studies in animals provide conflicting evidence ${ }^{810}$ on the ability of autotransplanted splenic tissue to restore protection against pneumococcal challenge, and the occurrence of overwhelming infections in patients with splenectomy despite the presence of splenosis or an accessory spleen ${ }^{2} 1130-32$ confirms that the presence of splenic tissue does not necessarily confer protection against the risks of splenectomy. It has been suggested that at least two factors are important in the ability of the "born again spleen" to confer resistance to infection-namely, a normal blood supply and the volume of splenic tissue. ${ }^{12}$ The latter seems to be particularly crucial, since in all but one ${ }^{11}$ of the cases of bacterial infections in patients with splenosis very small amounts of splenic tissue were found. ${ }^{2530-32}$ Moreover, while in the course of transplanting splenic tissue the surgeon cannot control the final blood supply to the tissue, he can determine the amount of splenic tissue to be implanted.

Until this paper no information about how much splenic tissue is necessary to restore splenic function was available. In 
this respect an extrapolation of the slow part of the curve in figure 4 shows that the intersection with the abscissa is at $180 \mathrm{~cm}^{3}$ - that is, to get a zero percentage of pitted red cells $180 \mathrm{~cm}^{3}$ of splenic tissue is needed, and this volume falls in the normal range of computed splenic volume. ${ }^{15}$

In animals autotransplanted splenic tissue undergoes almost complete necrosis followed by regeneration, ${ }^{33} 34$ and by the end of the fifth week after the graft the weight of the regenerated tissue equals the weight of the implanted tissue. ${ }^{34}$ We have shown a degree of return of splenic function with splenic volumes of not less than $20-30 \mathrm{~cm}^{3}$, and thus we suggest that at least $30 \mathrm{~cm}^{3}$ should be implanted. The peroperative measurement of this volume by a graduated tube containing sterile water is an easy and quick procedure which we recommend before implantation of splenic tissue.

We thank Professor M S Losowsky of Leeds (UK), for helpful discussion and invaluable advice on this work.

\section{References}

1 King H, Schumacker HB. Splenic studies. I. Susceptibility to infection after splenectomy performed in infancy. Ann Surg 1952;136:239-42.

Persectives intsplenectomy sepsis. In: Rosenberg HS, Bolande RP, eds. Perspectives in pediatric

3 Winkelstein JA. Splenectomy and infection. Arch Intern Med 1977;137:1516-7.

4 Schwartz PE, Sterioff S, Mucha P, Melton L Arch Intern Med 1977;137:1516-7. and mortality in adults. $\mathcal{F} A M A$ 1982;248:2279-83.

5 Balfanz JR, Nesbit ME, Jarvis C, Krivit $W$. Overwhelming sepsis following splenectomy for trauma. $\mathcal{f}$ Pediatr $1976 ; 88: 458-60$

Buchbinder JH, Lipkoff CJ. Splenosis: multiple peritoneal splenic implant following abdominal injury: a report of a case and review of the literature. Surgery 1939;6:927-34.

7 Jacob HS. Born again to work again. N Engl f Med 1978;298:1415-6. atel J, Williams JS, Naim JO, Hinshaw JR. Protection against pneumococcal sepsis in splenectomized rats by implantation of splenic tissue into an omental pouch. Surgery 1982;91:638-41.

Lanng Nielsen J, Hanberg Sorensen F, Sakso P, Hvid Hansen H. Implantation
of autologous splenic tissue after splenectomy for trauma. Br $\mathcal{F}$ Surg 1982;69:

10 Schwartz AD, Goldthorn JF, Winkelstein JA, Swift AJ. Lack of protective effect of autotransplanted splenic tissue to pneumococcal challenge. Blood 1978;51: R75-8.

Rice HM, James PD. Ectopic splenic tissue failed to prevent fatal pneumococcal septicaemia after splenectomy for trauma. Lancet $1980 ; \mathrm{i}: 565-6$.

2 Pearson HA, Johnston D, Smith KA, Touloukian RJ. "Born-again spleens" and resistance to infection. N Engl f Med 1978;299:832-3.

13 Pears Return of spleni

14 Corazza GR, Bullen AW, Hall R, Robinson PJ, Losowsky MS Simple method of assessing splenic function in coeliac disease. Clin Sci 1981;60:109-13.

15 Tauke WN, Soussaline F, Todd-Pokropek A, et al. Determination of organ volume

16 Coleman CN, McDougall IR, Dailey MO, Ager P, Bush S, Kaplan HS. Functional hyposplenia after splenic irradiation for Hodgkin's disease. Ann Intern Med 1982;96:44-7.

17 Bullen AW, Losowsky MS Consequences of impaired splenic function. Clin Sci $1979 ; 57: 129-37$.

18 Eichner ER. Splenic function: normal, too much and too little. Am $\mathcal{F}$ Med 1979;

19 O'Neal BJ, McDonald JC. The risk of sepsis in the asplenic adult. Ann Surg 1981; 194:775-8.

20 Kreuter E. Experimentelle untersuchungen uber die entstehung der sogenannten nebenmilzen insbesondere nach milzverletzungen. Bruns' Beirräge zur klinischen Chirurgie 1920;118:76-94.

21 Nielsen JL, Ellegaard J, Marqversen J, Hansen HH. Detection of splenosis and ectopic spleens with $9 \mathrm{~m}_{\mathrm{m}} \mathrm{T}$-labelled heat damaged autologous erythrocytes in 90 splenectomized patients. Scand 7 Haematol 1981;27:51-6.

22 Orda R, Barak J, Baron J, Spirer Z, Wiznitzer T. Postsplenectomy splenic activity. Ann Surg 1981;194:771-4.

23 Spencer GR, Bird C, Prothero DL, Brown TR, Mackenzie AF, Phillips MJ. Spleen scanning with "T $\mathrm{Tc}^{\mathrm{m}}$-labelled red blood cells after splenectomy. $B r \dot{\mathcal{F}}$ Surg $1981 ; 68: 412-4$.

24 Cohen EA. Splenosis: review and report of subcutaneous splenic implant. Arch Surg 1954;69:777-84

25 Fleming CR, Dickson ER, Harrison EG. Splenosis: autotransplantation of splenic tissue. Am $\mathcal{F}$ Med 1976 ;61:414-9.

27 WAMA 1980;243:1741-2. Arch Surg 1971;102:152-8.

28 Nielsen JL. Influence of residual splenic tissue on the presence of vacuolated erythrocytes in splenectomized patients. Scand f Haematol 1982;28:451-5.

29 Learmonth J. The surgery of the spleen. Br Med F 1951;ii:67. Massachusetts

31 Tanguy RL, Delalande JP, L'Azou M, Egreteau JP. Purpura fulminans a pneumocoques chez un adulte splénectomisé avec persistance de tissu splénique accessoire. Nour Presse Med 1981;27:2290.

32 Holmes FF, Weyandt T, Glazier J, Cuppage FE, Moral LA, Lindsey NJ.

Fulminant meningococcemia after splenectomy. FAMA 1981;246:1119-20.

ous fascia of the abdomen in rabbits. $\mathcal{F}$ Exp Med $1917 ; 25: 619-28$.

ous fascia of the abdomen in rabbits. F Exp Med 1917;25:619-28. autotransplants. Blood 1973;41:701-9.

(Accepted 24 fuly 1984)

\section{ONE HUNDRED YEARS AGO}

Mental power is brain-function as truly as manual power is musclefunction. The brain is as much part of the body as the hand. If the body be weak from lack of feeding, the strength of the limb fails. If the body be weak from lack of feeding, the strength of the brain fails. In the one case, manual power is lessened; in the other, mental power is reduced. The underfed can neither lift a heavy weight nor perform a relatively difficult or energetic act of cerebration. All this seems wonderfully simple; but, strangely enough, the authorities concerned in education appear to forget it. Attempts are made to cultivate the brains of growing children by instruction, while their little bodies are insufficiently fed, or, more accurately, half-starved. Surely, the great and persistent efforts which have been made to inform public opinion on this initial principle in the physiology of life and activity have not been wholly wasted; and yet it seems as though they had been, when we find the State and the community committed to a policy of forcing without feeding. We are bound by every consideration of duty and interest to undertake the education of the lower orders of the rising population, but it is folly to carry out the enterprise at the expense of the stock we are seeking to cultivate. What would be thought of the gardener who busied himself with the top of a plant, budding and training, without taking the trouble to see that its root was firmly bedded in good soil, and that it had an ample supply of nutriment ? The first thing that his master would do on becoming aware of his neglect or imbecility, would probably be to expel him from the nursery. He would be judged unfit for his task. This, however, is precisely what we are running the risk of doing with the young of our nation. We are cultivating their heads, while the organic necessity of eating and drinking is largely disregarded. If the little brain can be brought under the operation of the educator, the body of which that brain is a part may, many people seem to think, be left to take its chance. What makes the matter worse than it might otherwise be, is the fact that we are not simply or solely spending our thought for nought, because good mental work can never be got out of half-starved brains, but we are robbing the other parts of the body by drawing what little energy there may be to a single organ, that of the mind. Only one issue is possible; unfortunately for our race, it cannot be demonstrated until the next generation; then, however, the fatuity of a policy which under-estimates physical needs will stand confessed. The children of the children we are now forcing without feeding, must inevitably be deficient in muscular and general power and vitality. It is needless to write warmly on this point. We are plainly stating a proposition founded on inexorable laws of life and development. Setting aside all questions of immediate consequences, such as the breakdown of overtaught children in board-schools, as to which there is probably much exaggeration in particular cases, we have to face the fact that, by-and-by, when we are dead, the effects of our economic blunder will begin to make themselves apparent. This consideration should not be wholly disregarded. Meanwhile, although Mrs. Partington could not sweep back the Atlantic with a mop, it is within the reach of everybody to do something towards the mitigation of the mischief in progress. Let a determined endeavour be made to feed the poor little children who are subjected to an unwise and shortsighted policy of starvation and education. It would be difficult to name a more excellent enterprise in the interests of domestic life, now and in the future, than that of the organisations which have been formed to provide the children of the poor with good dinners. Every penny expended in this way is seed sown on a fruitful soil. The appeal for help which is now being made in the lay press deserves to be cordially supported. The matter is one in which outr profession cannot fail to take a lively interest. It is much to be desired that the movement may be extended, and that organisations, with the beneficial object of providing penny dinners for poor children, will be formed in all considerable localities. Those who desire information as to the best modes of carrying out this humane work will find an ample list of essays and papers published on the subject, in the letter of Mr. Fuller, which appeared in the Times of the 11th instant [October]. We may also call attention to the statistics of dinners provided at Rousdon School, Devonshire, recently issued by Sir Henry Peek, one of the prime movers in the matter. (British Medical Fournal 1884 ;ii :822.) 